\title{
New Media in Public Relations: A Study of New Media in Ragunan Zoo as a Tourism Destination
}

\author{
Diah Febrina \\ Umar Halim \\ Universitas Pancasila, Jakarta Indonesia \\ diahfebrina@univpancasila.ac.id \\ umarhalim@univpancasila.ac.id
}

\begin{abstract}
Globalization has made the inhabitants of the world interconnected more closely in almost every aspect of life because of the speed of information obtained. One of the important things that need to be considered in realizing the process of globalization is the development of information technology. The development of information technology has led to the emergence of new media. The new media is being used in various industries and business including in tourism industry. Public relation practitioners working in tourism industry take benefits of new media as means of communication and promotion. Ragunan Zoo is a tourist destination located in South Jakarta, Indonesia. The development of the era led to the development of strategy in introducing this tourism destination to local and overseas tourists. The types of new media that this tourism destination exploits are websites, social media, and mobile phone applications.
\end{abstract}

Keywords: Globalization; Information Technology; New Media; Public Relations.

\section{INTRODUCTION}

The phenomenon of the use of the internet in the world is increasingly showing a growing growth. Globally, internet users reach $49.7 \%$ of the total world population. This positive growth also occurs evenly in almost every country including Indonesia. In June 2019 , internet users reached $58.8 \%$ of the total population. This number represents $50.7 \%$ of internet users in the Asian region. The increase in the number of internet users was also followed by an increase in mobile phone subscribers. ITU World Telecommunication noted that between 2005 and early 2013 there were 6.8 billion customers approaching 7.1 billion world population (internetworldstats.com, 2019).

The increasing number of internet users around the world is a sign that information technology is growing. This is one of the important cases to realize the process of globalization. Globalization has made the world population more closely interconnected in almost all aspects of life due to the speed of information obtained. Globalization has also changed how people communicate and trade their businesses. Ruben \& Stewart (2006) say that this is an era where communication media have become an important place in human activity. Today, more than in the past, communication technology has 
become an impact in the personal and professional lives, associations and organizations, society and the world community.

Prasad (2011) said that in the context of globalization, world commerce must compete globally. The revolution in communication technology and media globalization is leading to a global economy based on knowledge and high-tech industries which will become a highly competitive global industry. The global industry is in the fields of biotechnology, health, products, telecommunications, entertainment, tourism and hospitality as well as others. Some studies show the existence of the use of information technology from these fields.

Among these studies is Ozad \& Kutoglu (2010) reviewing the use of the internet in educational media, Gomez \& Chalmeta (2011) using company web sites to communicate CSR programs to stakeholders, Umar \& Samsudin (2011) researching the use of ereligion among the younger generation, Petrovici (2014) about e-public relations, Levy \& Samsudin (2011) examined the use of the internet as an advertising medium and Sala, Gauchi \& Alhama (2017) studied the official website of Spanish tourism.

As part of the global industry, the phenomenon of tourism is a phenomenon that continues to be a concern in every country. Advances in communication information technology have also contributed greatly as a marketing communication tool for tourism, One of the professions that has a role in undergoing this field of communication is the lay communication profession.

This is in accordance with what Huertas (2008) said that public relations is an important part of the activities and communication of companies and tourism institutions. Public relations actors get an ease with the advancement of technology so as to create new media for communicating messages and information. This technological revolution makes practitioners in the public relations field look for various new ways of implementing their work (Wilcox, Ault, Agee, 2011)

\section{NEW MEDIA IN PUBLIC RELATIONS IN THE TOURISM INDUSTRY}

Kotler \& Keller (2009) provides an explanation that public relations includes various programs to promote or protect the image or product of individuals and companies. Jakovljevic (2010) says that public relations is a very effective way of communicating with target publics and promoting destinations. In his study of the role of public relations in Croatia as one of the tourism destinations, it was found that public relations provides a very important role in marketing Croatia as a tourism destination.

In building communication, public relations practitioners need communication media. Some scholars have revealed that historically, companies have used mass media in communicating with their publics and there has been a significant shift towards the use of the internet as a medium of communication (Chaudhri \& Wang 2007). Several studies have explored the use of new media in the field of public relations. Among these studies are Wang (2015) namely social media in public relations, Sutcu \& Bilbil (2008) on the use of new media technology in public relations firms in Turkey and Petrovic (2014) studying e-public relations as a case study of impact and efficiency. 
In addition, there is a study conducted by Vercic, Vercic \& Sriramesh (2015) who took a look at the use of new media in public relations. They examined 35 years of articles in the Public Relations Review to see the relationship between public relations and digital, social, mobile (DMS) media. In their writings, they say that scholars have long been interested in studying the phenomenon of use and impact rather than ICTs for public relations. Public relations actors get an ease with the advancement of technology so as to create new media for communicating messages and information.

The study conducted by Wang (2015) also added about the role of new media in the field of public relations. He said that social media had made a big impact on many disciplines and practices such as mass communication and public relations. One of the results of his study illustrates the important role of social media in public relations. In the tourism industry, public relations as a function of fostering communication to promote both names and destinations, new media plays a role in all activities carried out. This is evident through the study of Jakovljevic (2010) where it was informed that there was a significant increase in internet communication through the use of the World Wide Web to decide on the travel destinations chosen by travelers. Sala, Gauchi \& Alhama (2017) examines the official website of Spanish tourism. This study also evaluates key factors related to social media and web pages. In addition, Rojano \& Pamies (2015) in the results of his study provides important notes relating to the management of digital communications at destination destinations. He said that there was a clear interest in using social media as a communication tool to make a travel destination visible.

\section{METHOD}

This research uses a qualitative approach through media content analysis. New media analyzed were websites, Facebook, Twitter, Instagram and Ragunan Zoo Application. In addition, a descriptive quantitative approach through surveys is used to look at media usage among local tourists. A total of 104 local tourists have been drawn into the sample by purposive method. Data were analyzed univariately to find out the frequency and percentage of each question.

\section{RESULT}

\section{PUBLIC RELATIONS AND NEW MEDIA AT RAGUNAN ZOO}

Ragunan Wildlife Park or Ragunan Zoo is a tourist destination for animal parks covering an area of 147 hectares in South Jakarta. Ragunan Zoo has over 2,000 species of animals and 50,000 trees which make this park cool and comfortable. The animal park is also a conservation laboratory for rare animals (http://ragunanzoo.jakarta.go.id). According to the Department of Tourism \& Culture (Disparbud), Ragunan Wildlife Park 
in Jakarta has succeeded in becoming a major source of revenue value in Jakarta's rough city (KDNK), as well as an inspirational reference for other dealers in Indonesia to develop their tourist destinations (http: // www.budpar.go.id).

As a major tourist destination in Jakarta, Ragunan Zoo is a busy place visited by local travelers. Every year, there is a growing number of local tourists at Ragunan Zoo. Data on the number of travelers shows that in 2013 it reached 3.5 million and increased by 4.3 million in 2014. This number continues to show a positive direction where in 2016 it reached 5.1 million. Not only local travelers, foreign tourists also visit this destination. As of June 2017, 51 countries have visited this destination with travelers from the Asian region as the biggest contributor (http://ragunanzoo.jakarta.go.id). With the increasingly high level of competition in bringing travelers to a destination, the need for technology continues to push the destination to develop the ability to apply the latest technology. This is what continues to be done by Ragunan Zoo. One of them is by developing an entry ticket to the animal park in the form of e-ticketing.

In terms of establishing communication and fostering destination destinations, Ragunan Zoo's public relations actors have used a variety of new media. Among the new media used are web pages and Facebook, Twitter and Instagram social media. Then in 2015, in collaboration with mobile phone provider PT. Indosat, the Ragunan Zoo mobile phone application is introduced. The official Ragunan Zoo website includes various information about this animal park. Information provided includes information on visitors, types of plants and animals,

various facilities, various news and events, as well as Ragunan Zoo company profile. The website has been updated according to the needs. On the page Ragunan Zoo manager provides the latest information about the event, opening and closing Ragunan Zoo and provides directions. This webpage has two languages to make it easier for foreign travelers to access it. Here is the official website of Ragunan Zoo:
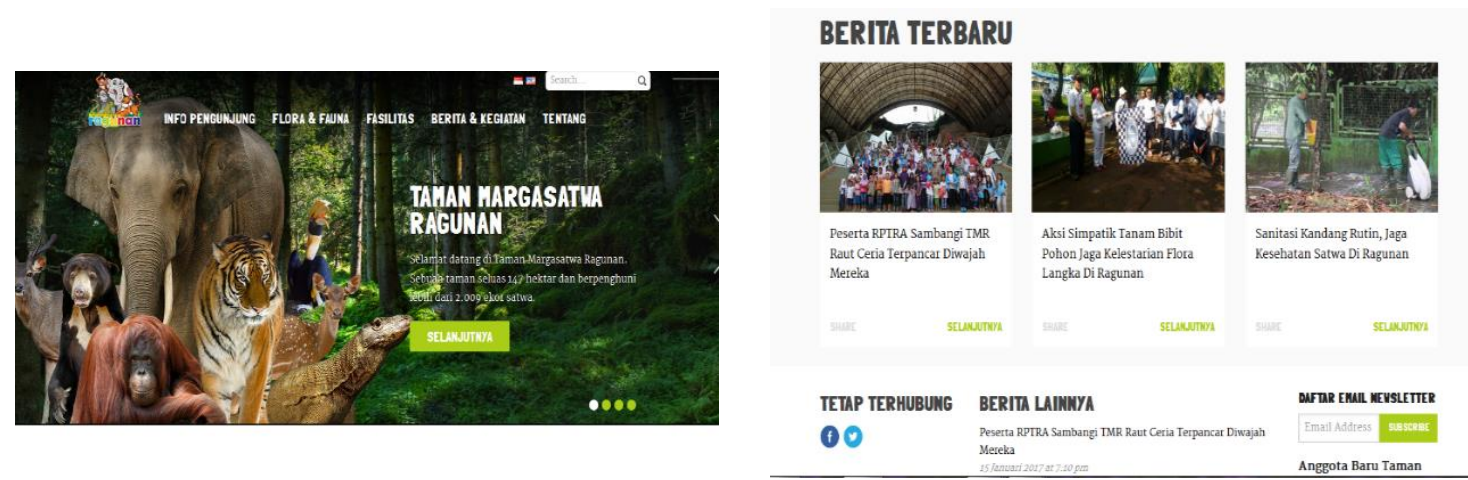

FIGURE 1. www. ragunanzoo.jakarta.go.id

The website is also linked to Ragunan Zoo's social media pages, Facebook and Twitter. Public relations practitioner try to integrate all communication media they have so that the public can choose what communication media suits them. In general, Facebook and Twitter pages contain information on activities and data on the number of visitors that are updated every day. If further observed it appears that both of these pages 
have almost the same information every day. Every information posted on Facebook is also on Twitter.

Apart from Facebook and Twitter, Ragunan Zoo currently also has an Instagram social page. This intends to facilitate the connoisseurs of photography because various photos are posted. The majority of the photos displayed on the Instagram page are photos of animals in this animal park. Not only relies on photos, public relations practitioners also provide education that is an explanation of the animals contained in the photo. Activities carried out by managers are also made public once in a while. This intends to foster a good image about the manager Ragunan Zoo.
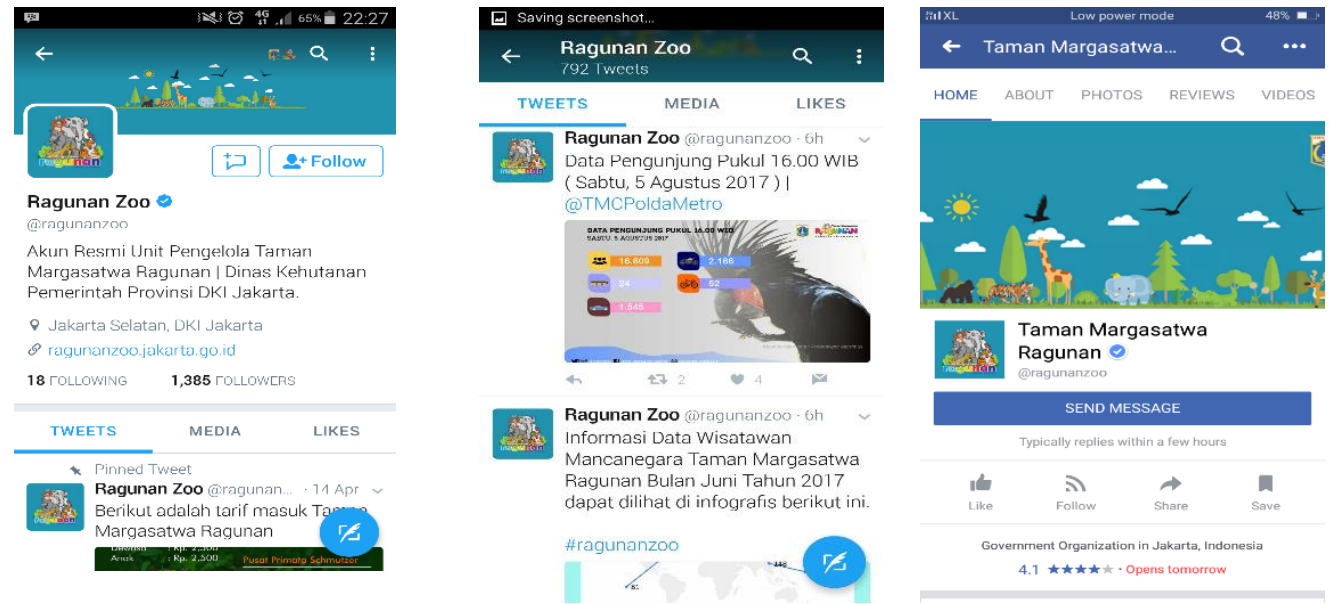

FIGURE 2. Twitter dan Facebook Ragunan Zoo

The latest communication media used by public relations practitioners Ragunan Zoo is a mobile phone application. This application can be obtained through Google Play Store named Ragunan Zoo. Ragunan Zoo application is an android based program of collaboration between Raguna Zoo managers and PT. Indosat. The main purpose of this application is to make Ragunan Wildlife Park more modern and increase the number of tourists to travel to Ragunan Zoo. Ragunan Zoo application will later become the foundation by the management of the animal park to help both tourists and foreign tourists in getting information about Ragunan Zoo.
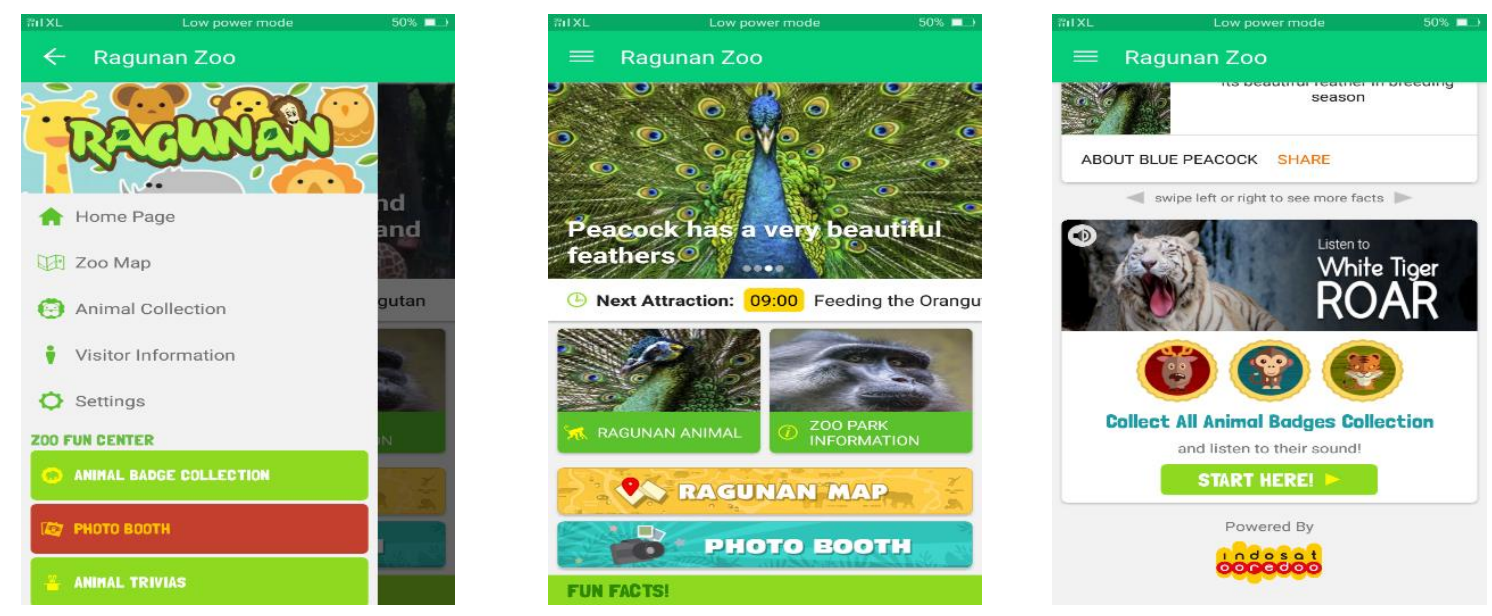
In addition, this application can help travelers who come to more easily access various kinds of the latest information about Ragunan Wildlife Park. The information contained in the "Ragunan Zoo Application" includes information on the attractions of animal performances such as horse riding and camel riding and the animal feeding schedule on a daily basis. The application also provides a map of the animal park area in digital form to facilitate tourists when in the Ragunan Zoo area. This map also shows the various facilities available such as the rest area, where to eat, and the parking area. This digital map is expected to reduce the number of travelers who are lost while in the region. Ragunan Zoo application also provides digital edutainment facilities to study various types of animals which are very numerous. There are also interactive games and animal sounds that are recorded to be heard by the users of this application. So far, 10 thousand users have downloaded this application on Google Play Store.

\section{USE OF MEDIA IN THE LOCAL TOURIST OF RAGUNAN ZOO}

The tourists were asked about the media channels that are often used to find out about Ragunan Zoo. There are nine media channels articulated in the question of inquiry, among those channels are akhbar / magazines, pamphlets, new media, internet, and mobile applications. Although access to new media is currently easy, this study does not become the dominant channel used by tourists.

TABLE 1. Media channels to get informations about Ragunan Zoo

\begin{tabular}{|c|c|c|c|c|c|}
\hline & $\begin{array}{c}\text { Never } \\
\%\end{array}$ & $\begin{array}{c}\text { Rarely } \\
\%\end{array}$ & $\begin{array}{c}\text { Occasionally } \\
\%\end{array}$ & $\begin{array}{c}\text { Often } \\
\%\end{array}$ & $\begin{array}{c}\text { Very } \\
\text { Often } \\
\%\end{array}$ \\
\hline - Newspaper/Magazine & 64.4 & 19.2 & 7.7 & 5.8 & 2.9 \\
\hline - Television & 37.5 & 20.2 & 20.2 & 20.2 & 1.9 \\
\hline - Pamphlet & 42.3 & 26 & 13.5 & 12.5 & 5.8 \\
\hline - Website & 53.8 & 19.2 & 14.4 & 10.6 & 1.9 \\
\hline - Facebook & 47.1 & 18.3 & 13.5 & 20.2 & 1 \\
\hline - $\quad$ Twitter & 67.3 & 11.5 & 11.5 & 7.7 & 1.9 \\
\hline - Instagram & 53.8 & 10.6 & 16.3 & 15.4 & 3.8 \\
\hline $\begin{array}{l}\text { - Mobile Application Ragunan } \\
\text { Zoo }\end{array}$ & 82.7 & 8.7 & 5.8 & 1.9 & 1 \\
\hline - Internet (google/search engine) & 25 & 14.4 & 23.1 & 36.5 & 1 \\
\hline
\end{tabular}

Table 1. shows that channels through the internet ie google / search engines are the dominant channels used by tourists $(36.5 \%$ often). These results illustrate that google / search engines are a trusted source for local tourists when they want to know about Ragunan Zoo. Although the development of mobile phone usage has increased 
significantly, the channels associated with this are not very often used by tourists. Of the five channels connected with new media, only Facebook is quite often used by tourists $(20.2 \%)$.

Interesting findings are on television channels. This channel is quite widely used by tourists to obtain information (20.2\%). However, this result is far different from the website pages and social media that are fostered by public relations Ragunan Zoo. Through this channel, tourists only use it a little, which is less than $20 \%$ who use it often. The lack of interest in tourists seeking information through these pages may indicate that these pages are still not popular with local tourists.

Aside from the media channels that are often used, the question of investigating in this study also asks about media channels that are often used when wanting to get further information about Ragunan Zoo. There are 11 types of information that were asked, including ticket prices, schedules, facilities, animal photos and maps / maps of Ragunan Zoo locations. The six media channels that are investigated in the question of investigation are media channels owned and maintained by public relations actors Ragunan Zoo. Although they have developed various new media in the business of promotion and providing information. Table 2 shows that this channel has not been fully utilized by local tourists.

TABLE 2. Media channels tourists uses

\begin{tabular}{|c|c|c|c|c|c|c|}
\hline \multirow[b]{2}{*}{ Kind of Informations } & \multirow[b]{2}{*}{$\begin{array}{c}\text { Facebook } \\
\%\end{array}$} & \multirow[b]{2}{*}{$\begin{array}{c}\text { Twitter } \\
\%\end{array}$} & \multirow[b]{2}{*}{$\begin{array}{c}\text { Instagram } \\
\%\end{array}$} & \multicolumn{3}{|c|}{ Mobile } \\
\hline & & & & $\begin{array}{c}\text { Website } \\
\%\end{array}$ & $\begin{array}{c}\text { Apps } \\
\text { Ragunan } \\
\text { Zoo } \\
\%\end{array}$ & $\begin{array}{c}\text { Informatio } \\
\text { n board / } \\
\text { pamphlet } \\
\%\end{array}$ \\
\hline - $\quad$ Ticket's prices & 5.8 & 1 & 0 & 32.7 & 1.9 & 58.7 \\
\hline - Schedules & 6.7 & 0 & 0 & 31.7 & 1.9 & 59.6 \\
\hline $\begin{array}{l}\text { - Animals schedules } \\
\text { attraction }\end{array}$ & 6.7 & 0 & 2.9 & 22.1 & 2.9 & 65.4 \\
\hline - Animal phothograph & 9.6 & 1 & 8.7 & 23.1 & 1.9 & 55.8 \\
\hline - Promotion & 6.7 & 0 & 7.7 & 24 & 2.9 & 58.7 \\
\hline - $\quad$ Kind of Animals & 3.8 & 1.9 & 3.8 & 25 & 1.9 & 63.6 \\
\hline - Facilities & 4.8 & 0 & 1 & 17.3 & 3.8 & 73.1 \\
\hline - Schedules of Event & 5.8 & 0 & 2.9 & 22.1 & 2.9 & 66.3 \\
\hline - The rules & 2.9 & 0 & 1 & 16.3 & 1 & 78.8 \\
\hline - $\quad$ Maps & 3.8 & 0 & 1.9 & 17.3 & 1 & 76 \\
\hline
\end{tabular}

Table 2 shows that the information board / pamphlet is the dominant channel for obtaining all types of announcements that are powered. Then followed by the official Ragunan Zoo website and on social media, Facebook remains a favorite of tourists. Of the six media channels, Twitter occupies the lowest position, which means that social media is quite widely used by tourists, but has not yet provided a notice that can satisfy the tourists 


\section{DISCUSSION \& CONCLUSION}

The development of communication technology has made public relations practitioners in the tourism industry use a variety of new media in marketing and developing destination images. The various types of new media that have been used by Ragunan Zoo generally provide an overview of the tourist destinations. Official website is a manifestation of the phenomenon of increasing use of web pages in the 21st century that crosses organizational boundaries. This is because the internet gives public relations practitioners the opportunity to disseminate information quickly and communicate with a larger audience. In addition, web pages are used to publish various activities to foster the image of the destination. This is in line with the opinion of Harris \& Whalen (2006) which states that the tool to be able to attract the public in publicizing an activity is by making newspapers, media tours, media events and one of them is through a website.

Communication through social media is also important and needs to be planned well. The use of Facebook, Twitter and Instagram social media will be useless if it does not have clear objectives. Brand communication must be a priority in communicating destinations. In the case of the use of photographs, Gonzalez \& Huertas (2015) stated that there must be a strategy for using photos to promote tourist destinations. Communicators should not only look for beautiful photos, but they must be able to communicate the name of the destination with various attractions and values.

The increase in internet usage can also be caused by an increase in mobile phone usage. By the means, public relations practitioners see great opportunities in the ease of communication and promoting Ragunan Zoo. Ragunan Zoo application on a mobile phone is expected to increase the number of tourists especially foreign tourists. This increase can be achieved if public relations actors can further popularize various media channels, especially new media channels owned by Ragunan Zoo.

\section{ABOUT THE AUTHORS}

Diah Febrina is a lecturer from the Faculty of Communication Science, Pancasila University, Jakarta. She is a Masters graduate from the Center for Media and Communication Studies, Faculty of Social Sciences and Humanities, Universiti Kebangsaan Malaysia.

Umar Halim is a lecturer and deputy dean of the Faculty of Communication Studies at the Pancasila University in Jakarta. He is a Masters graduate from the Center for Media and Communication Studies, Faculty of Social Sciences and Humanities, Universiti Kebangsaan Malaysia. 


\section{REFERENCES}

Chaudhri, V \& Wang, J. (2007). Communicating corporate social responsibility on the Internet: A case study of the top 100 IT companies in India. Management Communication Quarterly 21(2): 232-247.

Gomez, L.M \& Chalmeta, R. 2011. Corporate responsibility in U.S corporate websites: A pilot study. Public relations review 37: 93-95.

González, M.I.M \& Huertas, A. 2015. The power of photographs in the communication and public relations of tourist destinations and their brands through Facebook and Flickr. Catalan Journal of Communication \& Cultural Studies 7(2): 197-215.

Hassan, S.B., Hamid, M.S.A \& Bohairy, H. 2010. Perception of Destination Branding Measures: A Case Study of Alexandria Destination Marketing Organizations. International Journal of Euro-Mediterranean Studies 3(2): 269-288.

Harris, T. L \& Whalen, P.T. 2006. The Marketers Guide To Pblic Relations in the $21^{\text {st }}$ Century. United States of America: R.R. Donnelley

Huertas, A. 2008. Public relations and tourism: Fighting for the role of public relations in tourism. Public Relations Review 34: 406-408.

http://www.budpar.go.id [1 Agustus 2019]

http://internetworldstats.com [ 1 Agustus 2019]

http://ragunanzoo.jakarta.go.id [1 Agustus 2019]

Jakovljevic, M. 2010. The role of public relations in Croatia as a tourist destination. Tourism \& Hospitality Management, Conference Proceedings 101-113.

Kotler, P \& Keller, K.L. 2009. Manajemen pemasaran. Ed. ke-13. Jilid 2. Terj. Jakarta: Erlangga.

Levi, M.P \& Samsudin, A.R. 2011. Periklanan internet: Faktor pendorong yang merangsang pembelian produk kecantikan. Malaysian Journal of Communication Jilid 27(1): 1-17.

Ozad, B. E \& Kutoglu, U. 2010. The use of the internet in media education. The Turkish Online Journal of Educational Technology. 9(2): 245-255.

Petrovici, A. 2014. Public Relations in Tourism. A Research on The Perception of The Romanian Public Upon Responsible Tourism. Social and Behavioral Sciences 163: 67-72.

Petrovici, A. 2014. E- Public Relations: Impact and Efficiency. A case study. Social and Behavioral Sciences 141: 79-84.

Prasad, K. 2011. Media baru and public relations in Oman: Embracing innovation in the digital era. GMJ: Mediterranean Edition 6(2).

Rojano, F.J.P., Figueras N.R \& Pamies, D.S. 2015. The profile of public relations as a key to success for digital communication in tourist destinations. Catalan Journal of Communication \& Cultural Studies 7 (2): 147-162.

Ruben, B.D \& Stewart, L.P. 2006. Communication and human behavior. USA: Pearson Eduction, Inc. 
Sutcu, S.C \& Bilbil, E.K. 2008. Media baru in pr: A research on the utilization of media baru technologies in public relations firms in Turkey. The international journal of technology, knowledge and society 4(6).

Sala, A.M.M., Gauchi, J.M,. \& Alhama, C.C. 2017. Public relations in the tourism sector. Interactivity and social features of the official tourism websites of Spanish sun and beach destinations. Revista Latina de Comunicación Social 72: 374-396.

Umar, Halim \& Samsudin, A.R. 2011. Penglibatan digital: Akses dan penggunaan eagama dalam kalangan generasi muda muslim. Malaysian Journal of Communication 27(2): 121-135.

Vercic, D., Vercic, A.T \& Sriramesh, K. 2015. Looking for digital in public relations. Public Relations Review 41: 142-152.

Wang, Y. 2015. Incorporating social media in public relations: a synthesis of. social media-related public relations research. Journal Public Relations 9(3).

Wilcox, D.L, Ault, P H, \& Agee, W. 2011, Public Relations: Strategi dan Taktik. Jilid Dua. Terj. Tangerang Selatan: Karisma Publishing Group. 